\title{
ADP and AMP Induce Interleukin-1 $\beta$ Release from Microglial Cells through Activation of ATP-Primed P2X 7 Receptor Channels
}

\author{
Yassar Chakfe, ${ }^{1}$ Rosanne Seguin, ${ }^{2}$ Jack P. Antel, ${ }^{2}$ Céline Morissette, ${ }^{3}$ Danielle Malo,, Duncan Henderson, ${ }^{5}$ \\ and Philippe Séguéla ${ }^{1}$ \\ ${ }^{1}$ Cell Biology of Excitable Tissue Group and 2Neuroimmunology Unit, Montreal Neurological Institute, Montreal, Quebec, \\ Canada H3A 2B4, 3Department of Biology, Neurochem Inc., Saint-Laurent, Quebec, Canada H4S 2A1, ${ }^{4}$ Department of \\ Medicine and Human Genetics, McGill University, Montreal, Quebec, Canada H3G 1A4, and ${ }^{5}$ Department of Molecular \\ Biology, AstraZeneca Charnwood, Loughborough, United Kingdom LE11 5RH
}

$\mathrm{P}_{2} \mathrm{X}_{7}$ is a subtype of ATP-gated channels that is highly expressed in astrocytes, microglia, and other immune cells. Activation of $\mathrm{P}_{2} \mathrm{X}_{7}$ purinoceptors by ATP or 3'-O-(4-benzoyl)benzoyl ATP (BzATP) induces the formation of cytolytic pores and provokes release of interleukin- $1 \beta$ from immune cells. We investigated the actions of other endogenous nucleotides on recombinant and microglial $\mathrm{P}_{2} \mathrm{X}_{7}$ receptors using electrophysiology, fluorescence imaging, and interleukin- $1 \beta$ release measurement. We found that initial application of ADP or AMP to Xenopus oocytes expressing $\mathrm{P}_{2} \mathrm{X}_{7}$ receptors was ineffective. However, when ADP and AMP, but not UTP or adenosine, were applied after a brief exposure to ATP or BzATP, they activated

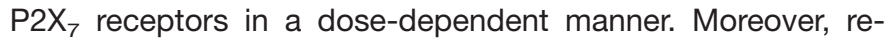
sponses to ADP and AMP were also elicited after exposure to low concentrations of ATP and were recorded several minutes after removal of ATP from the extracellular medium. Whole-cell recordings from mouse microglial cells showed that significant responses to ADP and AMP were elicited only after ATP application. YO-PRO-1 dye uptake imaging revealed that, unlike ATP, prolonged application of ADP or AMP did not cause an opening of large cytolytic pores in mouse microglial cells. Finally, ADP and AMP stimulated the release of interleukin-1 $\beta$ from ATP-primed mouse and human microglial cells. We conclude that selective sensitization of $\mathrm{P}_{2} \mathrm{X}_{7}$ receptors to ADP and AMP requires priming with ATP. This novel property of $P 2 X_{7}$ leads to activation by ATP metabolites and proinflammatory cytokine release from microglia without cytotoxicity.

Key words: nucleotides; purinoceptors; interleukin-1 $\beta$; cytokines; pore formation; microglia
Interleukin- $1 \beta$ (IL-1 $\beta$ ) is the principal proinflammatory cytokine induced in the brain as a result of systemic or local insult (Hopkins and Rothwell, 1995; Rothwell et al., 1997). It is readily expressed by microglia and meningeal macrophages within and around the ischemic area after stroke and brain damage (Minami et al., 1992; Liu et al., 1993; Buttini et al., 1994). Intracerebroventricular injection of the highly selective IL-1 receptor antagonist (Relton and Rothwell, 1992; Garcia et al., 1995) or IL-1 $\beta$ antibodies (Yamasaki et al., 1992, 1995) significantly reduced cerebral ischemia and neuronal loss in rodents, suggesting a direct role for IL- $1 \beta$ in the pathophysiology of stroke. IL- $1 \beta$ has also been implicated in several neurodegenerative diseases, such as amyotrophic lateral sclerosis (Pasinelli et al., 1999; Li et al., 2000), epilepsy (Vezzani et al., 1999, 2000), and multiple sclerosis (Martin and Near, 1995; Schijver et al., 1999). However, IL-1 $\beta$ promotes dopaminergic axonal sprouting in the nigrostriatal sys-

Received Nov. 28, 2001; revised Jan. 22, 2002; accepted Jan. 22, 2002.

This work was supported by an operating grant from the Canadian Institutes for Health Research and by AstraZeneca Charnwood. Y.C. is a recipient of a fellowship from the Savoy Foundation. P.S. is a Scholar of the Fonds de la Recherche en Santé du Québec. We thank A. Speelman for preparation of the oocytes, cell culture, and DNA preparations; Dr. P. Riccardi Castagnoli (University of Milan, Milan, Italy) for kindly providing the N9 microglial cell line; G. Sebastiani (Department of Biochemistry, McGill University) for technical assistance with ELISA; Drs. N. Tremblay and F. Gervais (Neurochem Inc.) for mouse microglia cultures; and Dr. C. Bourque (Department of Neurology, McGill University) for helpful comments during preparation of this manuscript.

Correspondence should be addressed to Dr. Philippe Séguéla, Montreal Neurological Institute, 3801 University Street, Montreal, Quebec, Canada H3A 2B4. E-mail: philippe.seguela@mcgill.ca.

Copyright (C) 2002 Society for Neuroscience $\quad 0270-6474 / 02 / 223061-09 \$ 15.00 / 0$ tem, suggesting that it may play a protective role in Parkinson's disease (Ho and Blum, 1997; Nishimura et al., 2000). In addition to its local actions, IL- $1 \beta$ mediates host-defense responses to systemic disease (e.g., infection and inflammation) by altering cardiovascular, immune, and neuroendocrine functions (Hopkins and Rothwell, 1995; Rothwell, 1999).

Microglia, resident macrophages in the CNS, constitute the major source of IL- $1 \beta$ secreted in response to neuronal damage (Giulian et al., 1986; Rothwell, 1999). Although the mechanisms underlying post-translational processing of IL- $1 \beta$ are not fully understood, depletion of cytoplasmic $\mathrm{K}^{+}$has been shown to be crucial for induction of IL-1 $\beta$-converting enzyme (ICE) activity and IL-1 $\beta$ release (Perregaux and Gabel, 1994). Extracellular ATP is the only endogenous compound known to cause a significant reduction in intracellular $\mathrm{K}^{+}$and consequent release of IL-1 $\beta$ (Perregaux and Gabel, 1994; Sanz and Di Virgilio, 2000). Substantial evidence currently exists suggesting a key role of $\mathrm{P} 2 \mathrm{X}_{7}$ ionotropic purinoceptors, nonselective cation channels permeable to $\mathrm{K}^{+}, \mathrm{Na}^{+}$, and $\mathrm{Ca}^{2+}$ with widespread distribution in immune cells (Collo et al., 1997), in ATP-induced IL-1 $\beta$ release. For example, macrophages and microglial cell lines pretreated with oxidized ATP (a P2X 7 antagonist; Ferrari et al., 1997a,b), microglial cell clones lacking $\mathrm{P} 2 \mathrm{X}_{7}$ but retaining $\mathrm{P} 2 \mathrm{Y}$ receptors (Ferrari et al., 1996), and macrophages pretreated with a monoclonal anti-P2X $\mathrm{X}_{7}$ antibody (Buell et al., 1998) all failed to induce IL- $1 \beta$ release when challenged with ATP. Moreover, ATP failed to induce IL- $1 \beta$ release from macrophages expressing mutant $\mathrm{P} 2 \mathrm{X}_{7}$ receptors, both in vivo and in vitro (Solle et al., 2001). 
Previous studies have shown that ADP (Perregaux and Gabel, 1994; Ferrari et al., 1997b), but not AMP, UTP, or GTP (Perregaux and Gabel, 1994), also triggers secretion of significant amounts of IL- $1 \beta$ from microglial cells and macrophages. The mechanism underlying the ADP-stimulated IL- $1 \beta$ release, however, remains unclear. We describe here a novel functional property of recombinant and microglial $\mathrm{P} 2 \mathrm{X}_{7}$ receptors by demonstrating their enhanced activation by ADP and AMP after priming with a brief ATP stimulation. Moreover, we show that this change in sensitivity to ADP and AMP is not related to the formation of large cytolytic pores, and that it underlies the ADPand AMP-induced release of IL- $1 \beta$ from microglial cells.

\section{MATERIALS AND METHODS}

Oocyte recording. Oocytes were surgically removed from Tricaïneanesthetized female Xenopus laevis frogs and were incubated with calcium-free Barth's solution containing type I collagenase $(1 \mathrm{mg} / \mathrm{ml}$; Life Technologies, Rockville, MD) at room temperature for $2 \mathrm{hr}$ under vigorous agitation. Stage V and VI oocytes were then manually defolliculated before intranuclear microinjection of supercoiled plasmid coding for mouse $\mathrm{P}_{2} \mathrm{X}_{7}\left(\mathrm{mP}_{2} \mathrm{X}_{7}\right)$, rat $\mathrm{P} 2 \mathrm{X}_{7}\left(\mathrm{rP} 2 \mathrm{X}_{7}\right)$, and $\mathrm{rP} 2 \mathrm{X}_{2}(5,1$, and 1 $\mathrm{ng}$, respectively). After injection, oocytes were incubated with Barth's solution containing $1.8 \mathrm{mM} \mathrm{CaCl} 2$ at $19^{\circ} \mathrm{C}$ for $24-72 \mathrm{hr}$ before electrophysiological recordings.

Two-electrode voltage-clamp recordings $\left(V_{\mathrm{H}}\right.$ of $\left.-60 \mathrm{mV}\right)$ were performed using glass pipettes (1-3 M $\Omega$ ) filled with $3 \mathrm{M} \mathrm{KCl}$ solution. Oocytes were placed in a recording chamber and were perfused at a flow

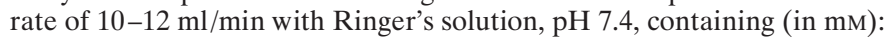
$\mathrm{NaCl} 115, \mathrm{NaOH} 5, \mathrm{KCl} 2.5, \mathrm{CaCl}_{2}$ 1.8, and HEPES 10. Membrane currents (DC, $1 \mathrm{kHz}$ ) were recorded through an $\mathrm{OC}-725 \mathrm{~B}$ amplifier (Warner Instruments, Hamden, CT) and digitized at $500 \mathrm{~Hz}$. Drugs were dissolved in the perfusion solution and applied using a computer-driven valve system. All recordings were made at room temperature.

Patch-clamp recording from culture microglial cells. N9 mouse microglial cells (Righi et al., 1989) were cultured in RPMI 1640 medium supplemented with $2 \mathrm{~mm}$ glutamine, plated onto $35 \mathrm{~mm}$ Petri dishes at a density of $1-5 \times 10^{5}$ cells per dish, and incubated at $37^{\circ} \mathrm{C}$ in $5 \% \mathrm{CO}_{2}$ for 24-72 hr before electrophysiology and YO-PRO-1 uptake imaging.

Whole-cell voltage-clamp recordings $\left(V_{\mathrm{H}}\right.$ of $\left.-65 \mathrm{mV}\right)$ were performed using pipettes filled with internal solution, $\mathrm{pH} 7.15-7.2$, containing (in $\mathrm{mm}$ ): K-gluconate $120, \mathrm{MgCl}_{2} 1, \mathrm{NaOH} 4$, and HEPES $10 \mathrm{~mm}$. Cells were mounted on the stage of an inverted phase-contrast microscope (Nikon, Tokyo, Japan) and perfused using an SF-77B fast perfusion system (Warner Instruments) at a rate of $1 \mathrm{ml} / \mathrm{min}$. The perfusion solution, $\mathrm{pH}$ 7.35, comprised (in $\mathrm{mm}$ ): $\mathrm{NaCl} 145, \mathrm{NaOH} \mathrm{5,} \mathrm{KCl} \mathrm{3,} \mathrm{MgCl}_{2}$ $1, \mathrm{CaCl}_{2}$ 0.9, and HEPES 10. Membrane currents (DC, $200 \mathrm{~Hz}$ ) were recorded through an Axopatch 200B amplifier (Axon Instruments, Foster City, CA) and digitized at $500 \mathrm{~Hz}$. All drugs were dissolved in the perfusion solution and delivered using a gravity-controlled fast fluid changer (SF-77B). All experiments were performed at room temperature.

YO-PRO-1 uptake imaging. The nucleotide-dependent increase in $\mathrm{P}_{2} \mathrm{X}_{7}$ pore diameter was assessed using YO-PRO-1 (Molecular Probes Inc., Eugene, OR) uptake, a 629 Da propidium di-iodide dye that fluoresces during binding to nucleic acids. Dishes were rinsed twice with the external solution used in electrophysiology to remove the cultured media and were then incubated with external solution containing $1 \mu \mathrm{M}$ YOPRO-1. Drugs were dissolved in the external solution (containing $1 \mu \mathrm{M}$ YO-PRO-1) and delivered using a fast perfusion system like the one used for electrophysiology. High divalent solution had the same composition as the external solution used for electrophysiology. Low divalent solution, $\mathrm{pH} 7.35$, comprised (in $\mathrm{mm}$ ): $\mathrm{NaCl} 145, \mathrm{NaOH} 5, \mathrm{KCl} 3, \mathrm{CaCl}_{2} 0.09$, and HEPES 10. Fluorescence changes were monitored in single cells (excitation, $491 \mathrm{~nm}$; emission, $509 \mathrm{~nm}$ ). Images were captured every 30 sec using Axon Imaging Workbench 2.2 software (Axon Instruments) and stored as Axon Imaging files. For priming experiments, ATP (1 mM) was applied for $10 \mathrm{sec}$, then washed out before application of ADP or AMP. Because nucleotides exhibited different levels of autofluorescence, background fluorescence was subtracted from all images before analysis.

$I L-1 \beta$ release assay. Primary cultured microglia from CD1 mice and from patients undergoing neurosurgical treatment for non-tumor-related intractable epilepsy were obtained as described previously by Aloisi et al.
(1999) and Yong and Antel (1992), respectively. Microglial cells were plated onto four well dishes at a density of $3 \times 10^{5}$ cells/well and incubated overnight at $37^{\circ} \mathrm{C}$ in $5 \% \mathrm{CO}_{2}$ to allow adherence. Lipopolysaccharide (LPS; $1 \mu \mathrm{g} / \mathrm{ml}$ ) was then added to all wells and incubated for $2 \mathrm{hr}$ before challenge with nucleotides. Hexokinase $(10 \mathrm{U} / \mathrm{ml}$ with $15 \mathrm{~mm}$ glucose) was added during LPS stimulation and then washed out before nucleotide application. Released IL- $1 \beta$ (in picograms per $3 \times 10^{5}$ cells/ $\mathrm{ml}$ ) was assayed using mouse or human IL-1 $\beta$ ELISA sets (Biosource Inc., Camarillo, CA; PharMingen, San Diego, CA).

Nucleotides. Nucleotides were purchased from Sigma (St. Louis, MO) and ICN (Santa Mesa, CA). The purity of ADP and AMP was $>98 \%$ and $>99 \%$, respectively. The ATP content in individual ADP and AMP lots was $0.0 \%$, as determined by chromatogram. If the ATP content in ADP and AMP products was unknown, we used the enzymatic purification described previously with apyrase for AMP and hexokinase for ADP (Traverso-Cori et al., 1970; Mahaut-Smith et al., 2000). Briefly, stocks of $10 \mathrm{~mm}$ ADP were incubated with $22 \mathrm{~mm}$ glucose and $7 \mathrm{U} / \mathrm{ml}$ hexokinase at $37^{\circ} \mathrm{C}$ for $1 \mathrm{hr}$. Stocks of $10 \mathrm{mM}$ AMP were incubated with $20 \mathrm{U} / \mathrm{ml}$ grade III apyrase for $1 \mathrm{hr}$ at $30^{\circ} \mathrm{C}, \mathrm{pH} 6.5$.

Statistical analysis. All values are reported as mean \pm SEM. Comparisons of the means between two groups were made using the paired $t$ test.

Comparisons of the means among more than two groups were performed using one-way ANOVA (Sigmastat 2.1; Jandel, San Rafael, CA) followed by Tukey's test for multiple comparisons to identify specific distinctions. Values were considered significant when $p<0.05$. Sigmoidal and exponential regressions were performed using SigmaPlot 5 software.

\section{RESULTS}

\section{Electrophysiological actions of nucleotides on recombinant $\mathrm{P} 2 \mathrm{X}_{7}$ receptors}

During two-electrode voltage-clamp recordings from Xenopus oocytes injected intranuclearly with $\mathrm{mP} 2 \mathrm{X}_{7} \mathrm{cDNA}$, initial application of $1 \mathrm{~mm}$ ADP induced a very small inward current $(0.07 \pm$ $0.05 \mu \mathrm{A} ; n=11)$ or had no effect $(n=3)$. Application of ATP (1 $\mathrm{mM}$ ) to the same oocytes, however, evoked a large inward current $(9.3 \pm 0.9 \mu \mathrm{A} ; n=14)$ that recovered rapidly with washing (Fig. $1 A)$. Interestingly, subsequent application of $1 \mathrm{~mm}$ ADP, after complete recovery of ATP response, induced a significantly larger inward current ( $2.97 \pm 0.70 \mu \mathrm{A} ; n=14 ; p<0.05$; paired $t$ test) (Fig. 1A). Initial application of $1 \mathrm{~mm}$ AMP induced no current $(n=4)$ or a very small inward current $(0.04 \pm 0.03 \mu \mathrm{A} ; n=3)$, but subsequent application, after recovery of ATP response $(10.13 \pm 1.59 \mu \mathrm{A} ; n=7)$, evoked a larger inward current $(0.31 \pm$ $0.24 \mu \mathrm{A} ; n=7)($ Fig. $1 B$ ) in all oocytes tested. It was reported previously that responses of megakaryocyte $\mathrm{P} 2 \mathrm{X}_{1}$ receptors to ADP application were actually a result of ATP contamination of commercial ADP (Mahaut-Smith et al., 2000). Responses to subsequent application of $1 \mathrm{~mm}$ hexokinase-purified ADP $(2.95 \pm$ $1.20 \mu \mathrm{A} ; n=8$ ) (Fig. $1 C$ ) and $1 \mathrm{~mm}$ apyrase-purified AMP $(0.24 \pm 0.14 \mu \mathrm{A} ; n=3)$ (Fig. $1 D)$ were larger than their initial responses, and they were comparable in amplitude with those obtained using nonpurified nucleotides. These results indicate that responses of $\mathrm{P} 2 \mathrm{X}_{7}$ receptors to ADP and AMP are not caused by ATP contamination of commercial nucleotide preparations. Moreover, repeated application of $1 \mathrm{~mm}$ ATP did not cause an increase in the amplitude of ATP-evoked current (data not shown).

The actions of ADP and AMP (1 mM each) on $\mathrm{mP}^{2} \mathrm{X}_{7}$ were also investigated before and after application of $300 \mu \mathrm{M} \mathrm{3}$ - $O$-(4benzoyl)-benzoyl ATP (BzATP). After complete recovery of a large response induced by BzATP $(6.86 \pm 0.89 \mu \mathrm{A} ; n=4)$, subsequent application of ADP evoked a significantly larger inward current $(2.39 \pm 0.75 \mu \mathrm{A} ; n=4 ; p<0.05)$ (Fig. $1 E)$ than that induced by initial application $(0.059 \pm 0.044 \mu \mathrm{A} ; n=4)$. In a similar manner, the current amplitude of AMP application to oocytes exposed previously to BzATP $(10.6 \pm 1.7 \mu \mathrm{A})$ was 
A

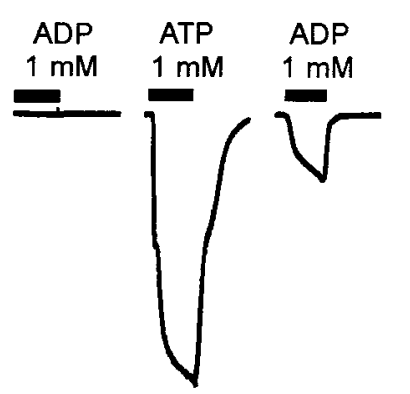

C

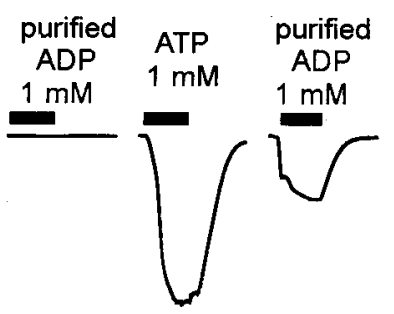

E

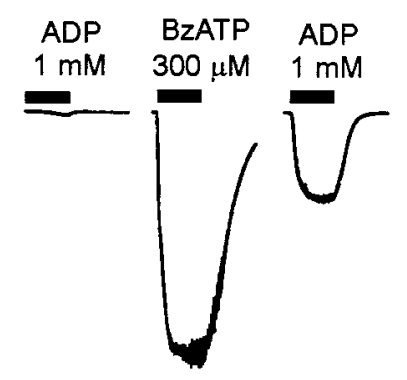

G

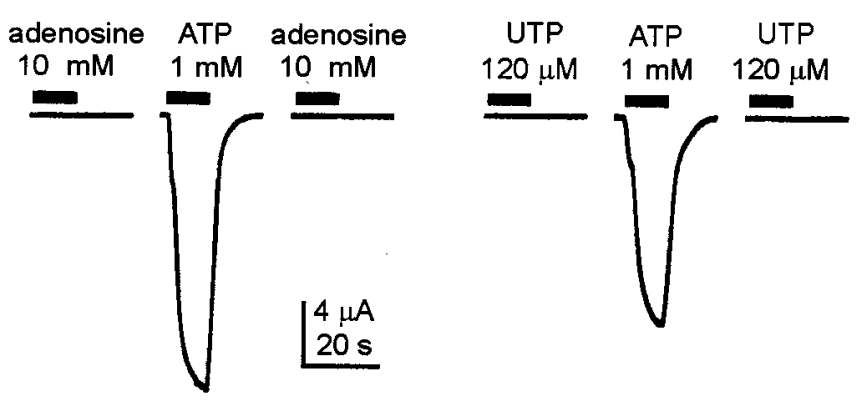

Figure 1. Actions of nucleotides and adenosine on recombinant mouse $\mathrm{P}_{2} \mathrm{X}_{7}$ receptors. Representative current responses from $\mathrm{mP}_{2} \mathrm{X}_{7^{-}}$ expressing oocytes to application of different nucleotides or adenosine before and after application of ATP $(1 \mathrm{mM})$ or BzATP $(300 \mu \mathrm{M})$ are shown. Responses to $1 \mathrm{~mm} \operatorname{ADP}(A), 1 \mathrm{~mm}$ AMP $(B), 1 \mathrm{~mm}$ hexokinasepurified ADP $(C), 1 \mathrm{mM}$ apyrase-purified AMP $(D), 10 \mathrm{~mm}$ adenosine $(G)$, or $120 \mu \mathrm{M}$ UTP $(H)$ before and after ATP are indicated. The response to $1 \mathrm{~mm} \operatorname{ADP}(E)$ or $1 \mathrm{~mm} \operatorname{AMP}(F)$ before and after BzATP is also shown. Drugs were applied for $10 \mathrm{sec}$ (solid bars) at $1 \mathrm{~min}$ intervals.

significantly larger $(1.3 \pm 0.4 \mu \mathrm{A} ; n=4 ; p<0.05)($ Fig. $1 F)$ than that of initial AMP application $(<0.04 \mu \mathrm{A})$. These responses were specific to the adenine nucleotides ADP and AMP, because no current response (initial or subsequent) was evoked by adenosine $(1-10 \mathrm{~mm} ; n=11)$ (Fig. $1 G)$ or by UTP $(10-120 \mu \mathrm{M} ; n=$

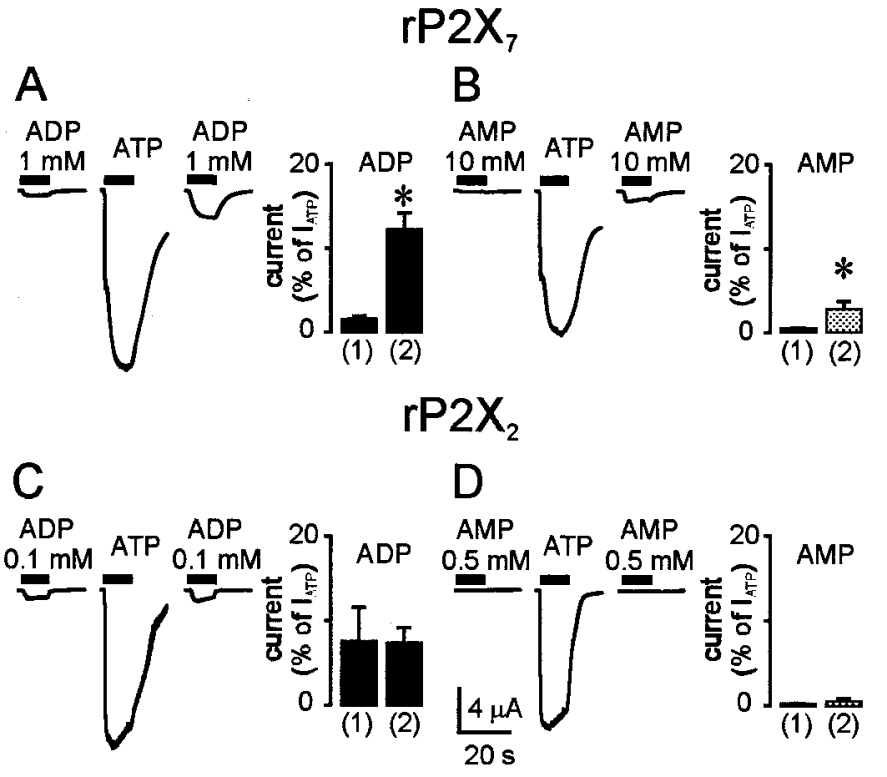

Figure 2. Actions of $\mathrm{ADP}$ and $\mathrm{AMP}$ on rat $\mathrm{P} 2 \mathrm{X}_{7}$ and rat $\mathrm{P} 2 \mathrm{X}_{2}$ receptor channels. Current responses from oocytes expressing rat $\mathrm{P} 2 \mathrm{X}_{7}$ to $1 \mathrm{~mm}$ $\operatorname{ADP}(A)$ and $10 \mathrm{~mm}$ AMP $(B)$ before and after $500 \mu \mathrm{M}$ ATP are shown. Current responses from oocytes expressing rat $\mathrm{P} 2 \mathrm{X}_{2}$ to $100 \mu \mathrm{M}$ ADP $(C)$ and $500 \mu \mathrm{M}$ AMP $(D)$ before and after $50 \mu \mathrm{M}$ ATP are also shown. Right panels of $A-D$, Relative amplitude (mean \pm SEM) of ADP- and AMP-induced current during initial (1) and subsequent (2) application. ${ }^{*} p<0.05$.

8) $($ Fig. $1 H)$. Moreover, none of the nucleotides tested induced detectable current responses in water-injected $(n=8)$ or noninjected $(n=25)$ oocytes, indicating the absence of endogenous metabotropic or ionotropic receptors activated by extracellular nucleotides (data not shown).

We then investigated the actions of nucleotides on $\mathrm{P} 2 \mathrm{X}_{7}$ from other species and on other $\mathrm{P} 2 \mathrm{X}$ subtypes. In rat $\mathrm{P} 2 \mathrm{X}_{7}$-injected oocytes, initial application of $1 \mathrm{~mm}$ ADP induced a small inward current $(0.19 \pm 0.05 \mu \mathrm{A} ; n=7)$ (Fig. $2 A)$. After recovery from a current response to $500 \mu \mathrm{M}$ ATP $(10.8 \pm 1.4 \mu \mathrm{A} ; n=7)$, application of ADP induced a significantly larger inward current $(1.27 \pm 0.22 \mu \mathrm{A} ; n=7 ; p<0.05)$ (Fig. 2A). Responses to subsequent application of $10 \mathrm{~mm} \operatorname{AMP}(0.24 \pm 0.11 \mu \mathrm{A} ; n=8)$ were also significantly greater than those obtained during initial application $(0.04 \pm 0.02 \mu \mathrm{A} ; n=8 ; p<0.05)$ (Fig. $2 B)$. We also examined the effects of ADP $(100 \mu \mathrm{M})$ and AMP $(500 \mu \mathrm{M})$ on oocytes expressing the rat $\mathrm{P} 2 \mathrm{X}_{2}$ receptors, a slowly desensitizing neuronal subtype, before and after application of $50 \mu \mathrm{M}$ ATP. As illustrated in Figure $2 C$, the current responses to initial $(0.71 \pm$ $0.25 \mu \mathrm{A} ; n=11)$ and subsequent $(0.95 \pm 0.22 \mu \mathrm{A} ; n=11)$ applications of ADP were not statistically different. Likewise, no significant difference was detected between responses to initial $(0.04 \pm 0.02 \mu \mathrm{A} ; n=9)$ and subsequent $(0.09 \pm 0.05 \mu \mathrm{A} ; n=9)$ applications of AMP in rat $\mathrm{P}_{2} \mathrm{X}_{2}$-expressing oocytes (Fig. $2 D$ ). Therefore, the dramatic potentiation of electrophysiological responses to the nucleotides ADP and AMP after administration of ATP or BzATP seems to be a distinct property of P2X $\mathrm{X}_{7}$ ATPgated channels.

\section{Dose dependency of ADP and AMP responses}

Dose-response relationships of the ADP and AMP effects on $\mathrm{mP}_{2} \mathrm{X}_{7}$ receptor channels were determined using the same concentration of each nucleotide $1 \mathrm{~min}$ before and $1 \mathrm{~min}$ after 


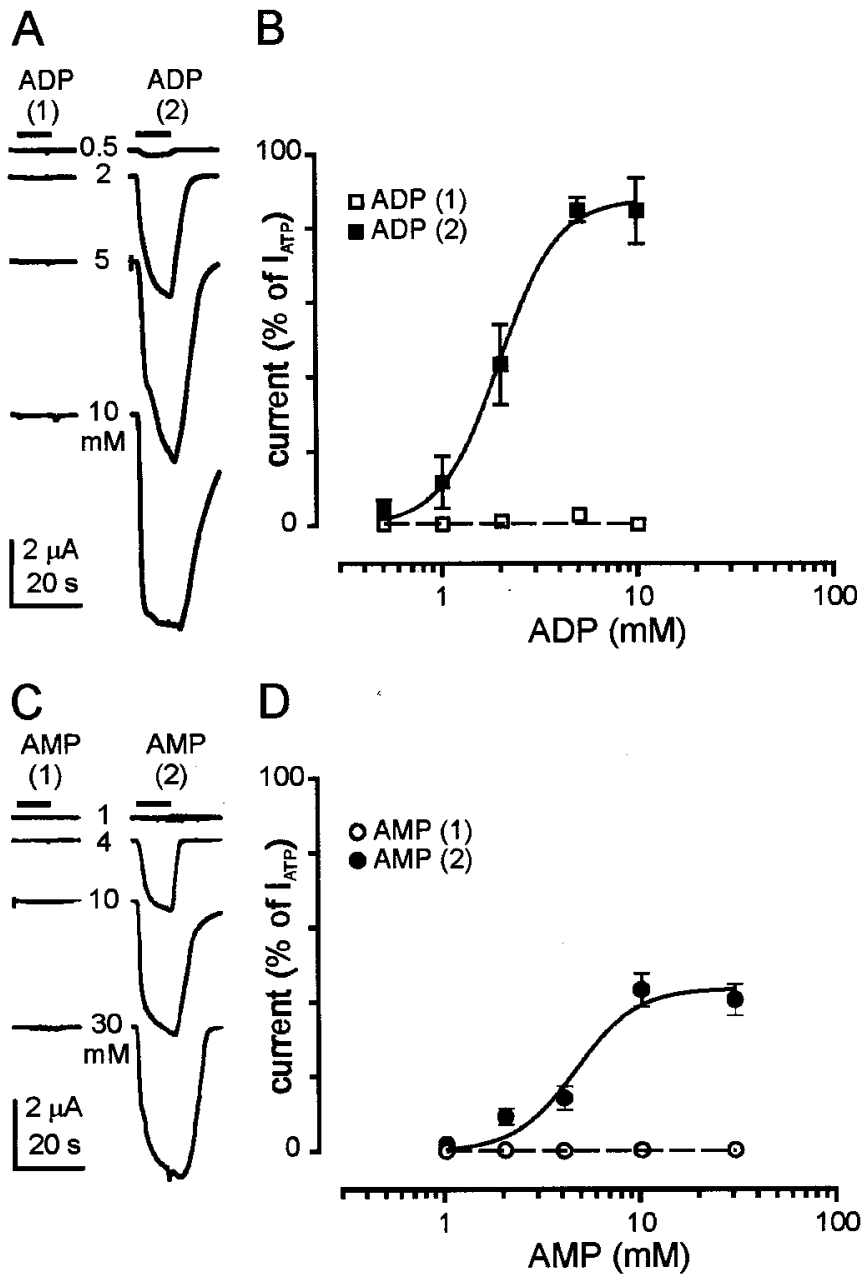

Figure 3. Dose-response relationship of ADP and AMP on mouse $\mathrm{P} 2 \mathrm{X}_{7}$ receptors. $A$, Current responses of $\mathrm{mP} 2 \mathrm{X} 7$-expressing oocytes to different concentrations of ADP before (1) and after (2) application of $1 \mathrm{~mm}$ ATP. $B$, Normalized dose-response curves of ADP-evoked current before (open squares) and after (filled squares) application of $1 \mathrm{~mm}$ ATP. The solid line is a nonlinear regression through data points using the three-parameter logistic equation $\left(n_{\mathrm{H}}=2.87 \pm 0.49 ; r=0.99\right)$; the dashed line is a straight line through data points. $C$, Current responses of $\mathrm{mP} 2 \mathrm{X} 7$-expressing oocytes to different concentrations of AMP before (1) and after (2) application of $1 \mathrm{mM}$ ATP. D, Normalized dose-response curves of AMP-evoked current before (open circles) and after (filled circles) application of $1 \mathrm{~mm}$ ATP. The solid line is a nonlinear regression using the three-parameter logistic equation $\left(n_{\mathrm{H}}=2.79 \pm 1.58 ; r=0.98\right)$. The dashed line is a straight line through data points. Note the absence of a dose-response relationship for ADP or AMP before ATP application. Drugs were applied for $10 \mathrm{sec}$ at 1 min intervals.

application of $1 \mathrm{mM}$ ATP. Figure $3 A$ shows that the current responses to initial ADP application $(0.5-10 \mathrm{~mm})$ were undetectable or very small $(<0.1 \mu \mathrm{A})$. However, application of ADP, after ATP stimulation, induced a robust inward current that clearly increased in amplitude in a dose-dependent manner, with a maximal response achieved at $5 \mathrm{~mm}$ and an $\mathrm{EC}_{50}$ of $1.98 \pm 0.12 \mathrm{~mm}$ (Fig. $3 A, B)$. Analogously, current responses to initial application of AMP $(1-30 \mathrm{~mm})$ were also undetectable or very small $(<0.06$ $\mu \mathrm{A})$ (Fig. $3 C$ ). After ATP stimulation, AMP-induced current displayed a sigmoidal dose-response relationship, with a maximal response achieved at $10 \mathrm{~mm}$ and an $\mathrm{EC}_{50}$ of $4.6 \pm 1.1 \mathrm{~mm}$ (Fig. $3 C, D)$. The maximal response obtained with ADP comprised $85 \pm 9 \%$ of ATP-induced current $\left(I_{\text {ATP }}\right)$ and was significantly
A
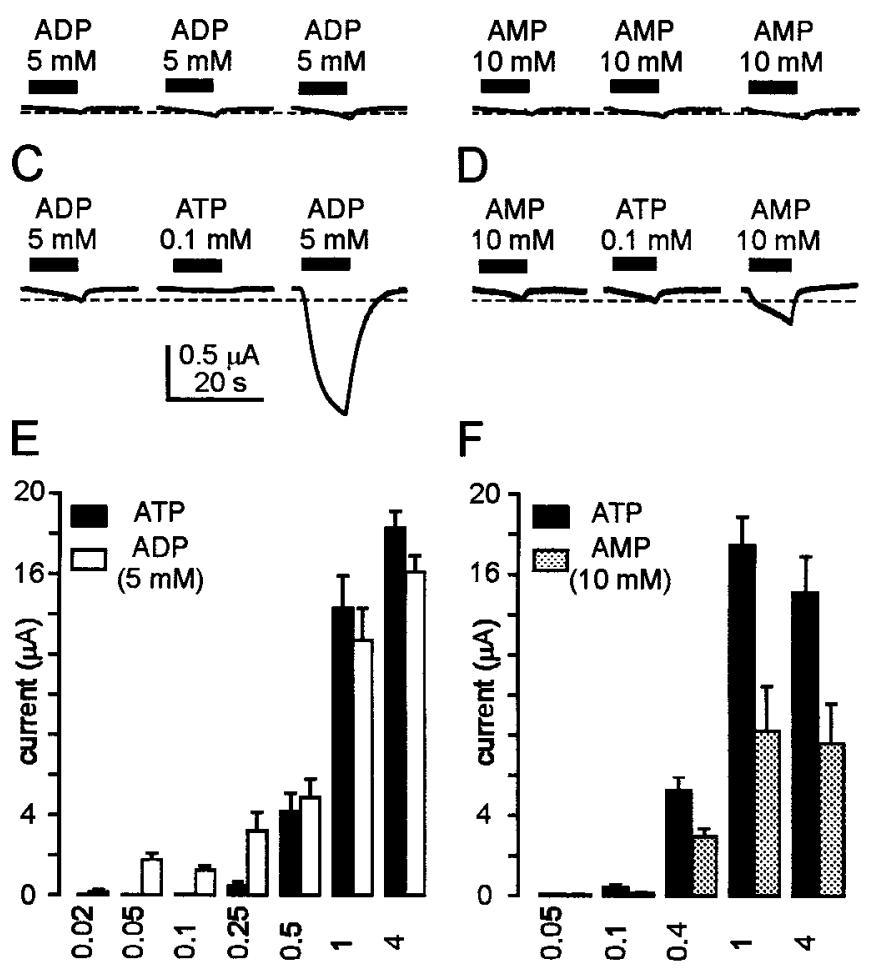

Figure 4. ATP primes mouse $\mathrm{P}_{2} \mathrm{X}_{7}$ receptors for subsequent applications of ADP and AMP. Representative current responses from two $\mathrm{mP}^{2} \mathrm{X}_{7^{-}}$ expressing oocytes to repeated application of $5 \mathrm{~mm} \operatorname{ADP}(A)$ or $10 \mathrm{~mm}$ AMP $(B)$ are shown. Note the absence of enhancement of the nucleotideevoked current amplitude. Responses to $5 \mathrm{~mm}$ ADP $(C)$ or $10 \mathrm{~mm}$ AMP $(D)$ before and after application of $100 \mu \mathrm{M}$ ATP in $\mathrm{mP}_{2} \mathrm{X}_{7}$-expressing oocytes are also shown. Peak response to initial drug application is indicated by dashed lines. $E$, Current amplitude (mean \pm SEM) of ADP ( $5 \mathrm{~mm}$; open bars) paired with the corresponding preceding ATP-evoked current (solid bars) at different concentrations (in mM, numbers below solid bars). F, Current amplitude (mean \pm SEM) of AMP (10 mM; gray bars) paired with the corresponding ATP-evoked priming current (solid bars) at different concentrations (in mM, numbers below solid bars).

larger than the maximal response achieved with AMP $(43 \pm 4 \%$ of $\left.I_{\mathrm{ATP}}\right)$, indicating that both nucleotides are partial agonists for $\mathrm{mP}_{2} \mathrm{X}_{7}$ exposed previously to ATP, with ADP being more potent and more efficacious.

\section{ATP produces a long-lasting priming of $\mathbf{P} 2 \mathbf{X}_{\mathbf{7}}$ receptors}

Repeated application of ADP and AMP at their maximal concentrations ( 5 and $10 \mathrm{~mm}$, respectively) did not induce an increase in the current amplitude (Fig. 4A,B). Strikingly, the current responses to ADP and AMP were potentiated after stimulation with low ATP concentrations (e.g., $100 \mu \mathrm{M}$ ) (Fig. 4C,D). As illustrated in Figure $4 E, F$, the magnitude of ADP- and AMPinduced currents was dependent on the preceding ATP concentration, reaching maximal levels at saturating ATP concentrations ( $\geq 1 \mathrm{~mm}$ ). Moreover, after any ATP concentration, the ADP response was much larger than the AMP response. These results indicate that ATP stimulation is necessary to prime $\mathrm{P} 2 \mathrm{X}_{7}$ receptors for subsequent activation by ADP and AMP.

To test how long $\mathrm{P}_{2} \mathrm{X}_{7}$ receptors remain primed with brief exposure to ATP, ADP and AMP were applied at various intervals after removal of ATP from the extracellular medium. As shown in Figure $5 A, B$, significant responses to ADP ( $5 \mathrm{~mm}$ ) and 
A

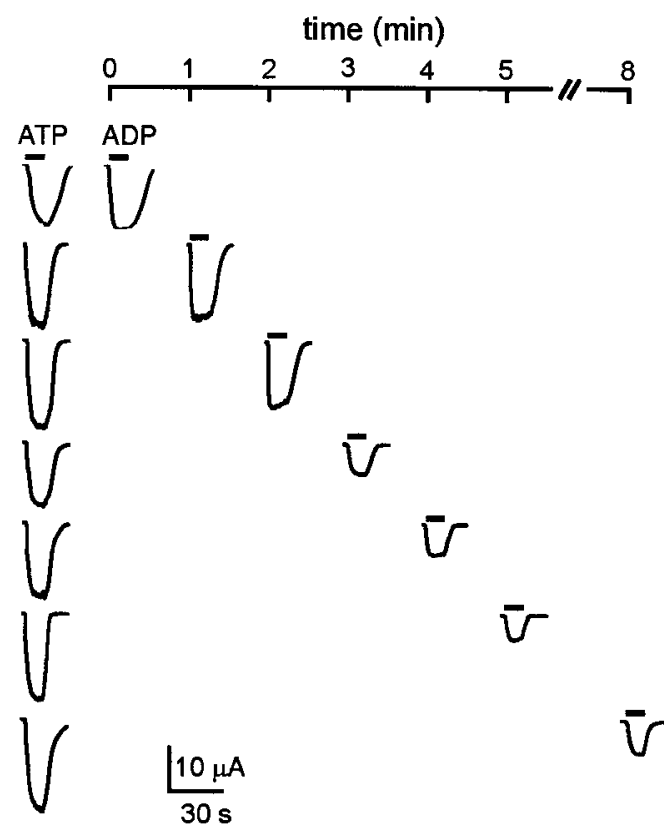

\section{B}

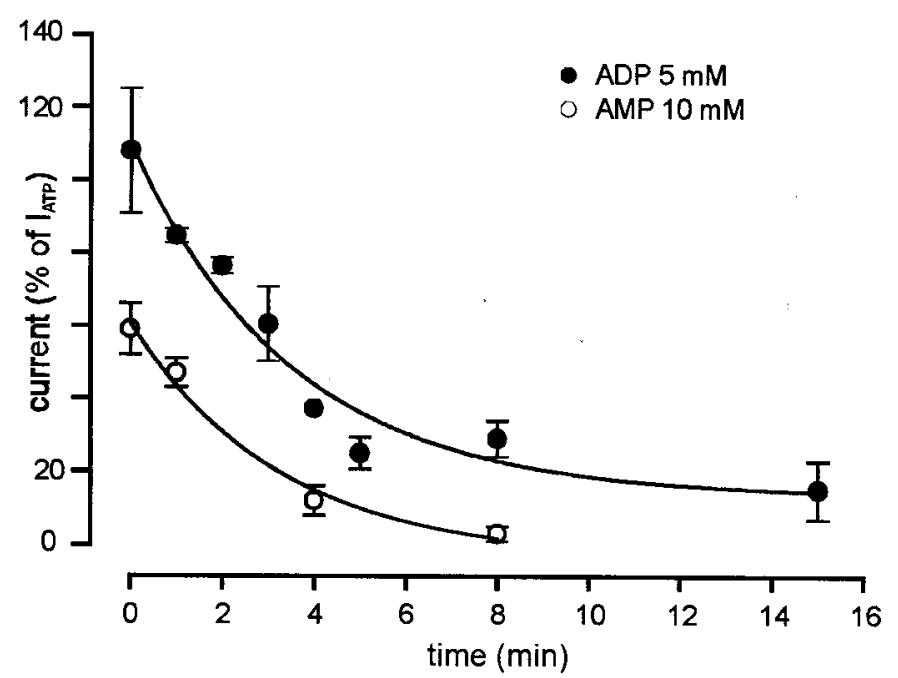

Figure 5. Time course of ATP priming on mouse $\mathrm{P} 2 \mathrm{X}_{7}$ receptors. $A$, Recordings from $\mathrm{mP}_{2} \mathrm{X}_{7}$-expressing oocytes showing current responses to $5 \mathrm{~mm}$ ADP applied at different intervals after $1 \mathrm{mM}$ ATP application. $B$, Normalized ADP-evoked currents (mean \pm SEM, solid circles) and AMP-evoked currents (mean \pm SEM, open circles) represented as percentage of ATP-induced current $\left(I_{\mathrm{ATP}}\right)$ at different times after ATP application. Solid lines are monoexponential fits with $\tau=3.4 \mathrm{~min}, r=0.98$ and $\tau=3.2 \mathrm{~min}, r=0.99$ for ADP and AMP, respectively.

AMP (10 mM) could still be elicited several minutes after ATP application but at a lesser magnitude (e.g., ADP response at 15 min was $15 \pm 8 \%$ of $\left.I_{\mathrm{ATP}}\right)$. Moreover, at any given time, ADP produced a larger response than AMP. The time constant of the ATP priming effect was $\approx 3$ min as measured by the exponential decay of the current responses to ADP and AMP (Fig. 5B). These results indicate that brief exposure to ATP produces a longlasting priming effect on $\mathrm{P}_{2} \mathrm{X}_{7}$ receptor channels during which exposure to either ADP or AMP may produce a notable current response.
A

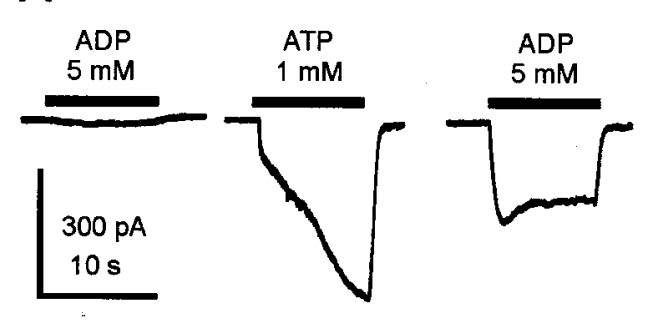

C

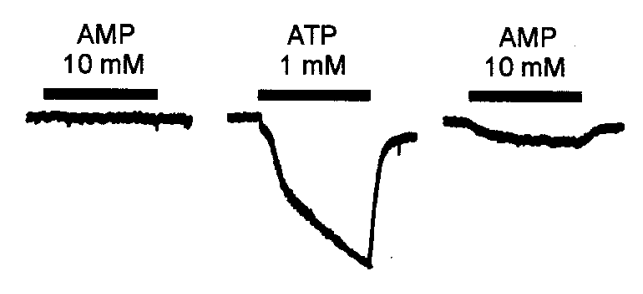

D
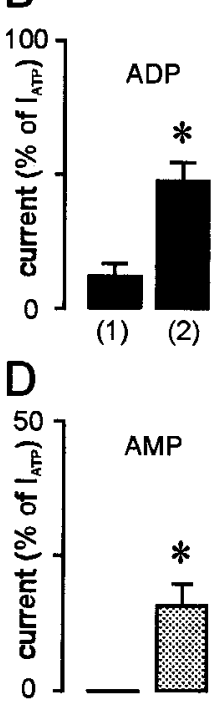

(1)

Figure 6. ATP primes N9 mouse microglial cells for ADP and AMP. A, Patch-clamp recording from one N9 cell showing typical current responses to $5 \mathrm{~mm}$ ADP applied $1 \mathrm{~min}$ before and $1 \mathrm{~min}$ after application of $1 \mathrm{~mm}$ ATP. $B$, Relative amplitude (mean \pm SEM) of ADP-evoked currents corresponding to initial (1) and subsequent (2) applications of ADP. $C$, Current responses from another N9 cell to $10 \mathrm{mM}$ AMP before and after $1 \mathrm{~mm}$ ATP. The histogram in $D$ shows normalized AMP-evoked currents (mean \pm SEM) in response to initial (1) and subsequent (2) application of AMP. ${ }^{*} p<0.05$.

\section{Electrophysiological actions of ADP and AMP on microglial cells}

P2X $\mathrm{X}_{7}$ ATP-gated channels are highly expressed in microglia and other immune cells (Collo et al., 1997). We therefore investigated the electrophysiological actions of ADP and AMP on N9 mouse microglial cells using whole-cell voltage-clamp recording. In agreement with the data obtained in oocytes, initial application of $5 \mathrm{~mm}$ ADP induced a small inward current $(33 \pm 7 \mathrm{pA} ; n=8)$ or no current $(n=3)$. However, after recovery of the ATP-induced current $(361 \pm 99 \mathrm{pA} ; n=11)$, application of ADP induced a significantly larger current $(170 \pm 55 \mathrm{pA} ; n=11 ; p<0.05)$ (Fig. $6 A, B)$. Likewise, no current response was elicited with an initial application of $10 \mathrm{mM}$ AMP $(n=5)$. After return to baseline of ATP-induced current $(211 \pm 39 \mathrm{pA})$, application of AMP evoked an inward current $(27 \pm 4 \mathrm{pA} ; n=5 ; p<0.05)$ (Fig. 6C,D). Because microglial cells express $\mathrm{P} 2 \mathrm{Y}$ metabotropic as well as $\mathrm{P}_{2} \mathrm{X}_{7}$ ionotropic purinoceptors (Wang et al., 1999), we tested whether P2Y receptors are involved, at least in part, in the enhanced ADP and AMP responses. No significant difference was observed between initial and subsequent ADP- or AMPinduced current recorded before and after application of $10 \mu \mathrm{M}$ UTP (data not shown). Thus, the enhanced ADP and AMP responses in mouse N9 microglial cells are mediated through ATP-primed $\mathrm{P}_{2} \mathrm{X}_{7}$ receptor channels.

\section{ADP and AMP do not cause opening of large pores in microglial cells}

Repeated or continuous application of ATP induces formation of large nonselective pores in native and transfected cells expressing $\mathrm{P}_{2 \mathrm{X}}$ receptor channels (Ferrari et al., 1996; Surprenant et al., 1996; Rassendren et al., 1997; Chessell et al., 1998). We therefore investigated whether ADP and AMP can provoke $\mathrm{P}_{2} \mathrm{X}_{7}$-mediated 

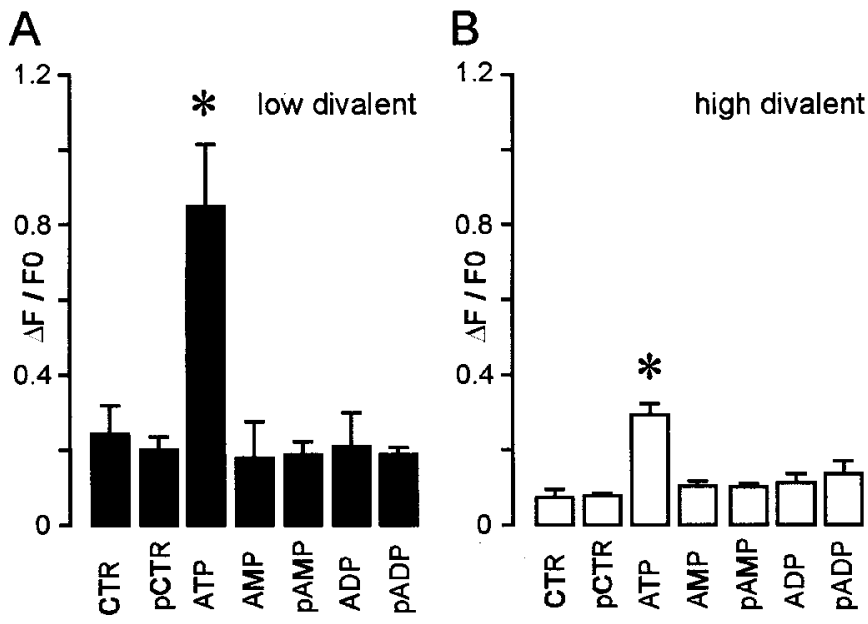

Figure 7. ADP and AMP do not induce permeabilization of N9 microglial cells. Bar histograms of the mean ( \pm SEM) $\Delta F / F 0$ YO-PRO uptake in response to different nucleotides in low divalent $(A)$ and in high divalent $(B)$ solutions are shown. Data are reported at 25 min. $p A M P$ and $p A D P$ indicate that cells were primed with ATP for $10 \mathrm{sec}$ and then washed for $1 \mathrm{~min}$ before continuous application of either AMP or ADP. $p C T R$ indicates that cells were primed with ATP for $10 \mathrm{sec}$ and then washed for the rest of the experiment with control (CTR) solution. ${ }^{*} p<0.05$.

pore dilation in N9 mouse microglial cells using YO-PRO-1 uptake imaging. In both high and low divalent solutions, YOPRO-1 uptake did not increase above background when $1 \mathrm{~mm}$ ATP was applied briefly (10 sec) (Fig. 7). However, the intensity of the dye uptake in response to repeated or continuous application of $1 \mathrm{~mm}$ ATP increased significantly over time, with higher uptake measured in low divalent solution (Fig. 7). In contrast, ADP or AMP, with and without ATP priming, did not induce a significant increase in YO-PRO-1 uptake (Fig. 7). The dilation of $\mathrm{P}_{2} \mathrm{X}_{7}$ pores in N9 mouse microglial cells, therefore, is specific to prolonged or repeated application of ATP, not ADP or AMP.

\section{ADP and AMP induce IL-1 $\beta$ release from ATP-primed microglial cells}

Activation of $\mathrm{P}_{2} \mathrm{X}_{7}$ receptor channels by ATP provokes IL-1 $\beta$ release from LPS-stimulated microglial cells (Ferrari et al., 1996, 1997b) and macrophages (Ferrari et al., 1997a). We investigated the effects of ADP and AMP on IL-1 $\beta$ release from LPSstimulated (1 $\mu \mathrm{g} / \mathrm{ml}$ for $2 \mathrm{hr}$ ) microglial cells and examined the role of ATP priming in such release.

In $\mathrm{N} 9$ mouse microglial cells, IL-1 $\beta$ release in response to application of $10 \mathrm{~mm}$ AMP (without priming; $131 \pm 41 \mathrm{pg} / \mathrm{ml}$; $n=4$ ) was not different from controls (LPS only; $111 \pm 55 \mathrm{pg} / \mathrm{ml}$; $n=5$ ). However, AMP, after ATP priming, induced significant IL- $1 \beta$ release $(347 \pm 69 \mathrm{pg} / \mathrm{ml} ; n=4 ; p<0.05$, one-way ANOVA) (Fig. $8 A$ ). In contrast, ADP (5 mM) without ATP priming produced a significant release of IL-1 $\beta(445 \pm 101 \mathrm{pg} / \mathrm{ml}$; $n=7)$ that was not different from that obtained after ATP priming $(402 \pm 51 \mathrm{pg} / \mathrm{ml} ; n=5)$ or with ATP alone $(413 \pm 128$ $\mathrm{pg} / \mathrm{ml} ; n=4 ; p>0.05$ ) (Fig. $8 A$ ). Several cell types, including microglial cells (Ferrari et al., 1997b,c), release small amounts of ATP after LPS stimulation, leading to the formation of an autocrine loop at the level of $\mathrm{P} 2 \mathrm{X}_{7}$ receptors. We therefore sought to disrupt this autocrine loop by incubating microglial cells with hexokinase during LPS stimulation to convert endogenously released ATP into ADP. After the hexokinase treatment, ADP failed to provoke IL-1 $\beta$ release from N9 microglial cells $(46 \pm 10$ $\mathrm{pg} / \mathrm{ml} ; n=3$ ) (Fig. $8 A$ ).

In primary cultured mouse microglia, the release of IL- $1 \beta$ in response to $10 \mathrm{~mm}$ ADP, without experimental ATP priming, was $1120 \pm 261 \mathrm{pg} / \mathrm{ml}(n=3)$, which was not different from that obtained after ATP priming $(866 \pm 33 \mathrm{pg} / \mathrm{ml} ; n=3)$ or in response to ATP alone $(771 \pm 98 \mathrm{pg} / \mathrm{ml} ; n=3)$ (Fig. $8 B$ ). After treatment with hexokinase, however, ADP-induced IL- $1 \beta$ release was negligible $(76 \pm 14 \mathrm{pg} / \mathrm{ml} ; n=3)$ (Fig. $8 B$ ). Similarly, AMP-induced IL-1 $\beta$ release without ATP priming $(577 \pm 106$ $\mathrm{pg} / \mathrm{ml} ; n=3$ ) was not different from that evoked by the same agonist after ATP priming $(675 \pm 30 \mathrm{pg} / \mathrm{ml} ; n=3)$. Pretreatment with hexokinase inhibited the AMP-induced IL- $1 \beta$ release $(68 \pm$ $9 \mathrm{pg} / \mathrm{ml} ; n=3$ ) (Fig. 8B).

In primary cultured human microglia, IL- $1 \beta$ release in response to $1 \mathrm{~mm}$ ATP was $207 \pm 20 \mathrm{pg} / \mathrm{ml}(n=3)$. IL- $1 \beta$ release in response to ADP and AMP (10 mM each) was $57 \pm 20 \mathrm{pg} / \mathrm{ml}$ $(n=3)$ and $16 \pm 8 \mathrm{pg} / \mathrm{ml}(n=3)$, respectively, and was not significantly different from controls $(34 \pm 7 \mathrm{pg} / \mathrm{ml} ; n=3$ ) (Fig. $8 C)$. After ATP priming, both nucleotides provoked significant release of IL-1 $\beta(152 \pm 13 \mathrm{pg} / \mathrm{ml}, n=3$ for ADP; $113 \pm 21 \mathrm{pg} / \mathrm{ml}$, $n=3$ for AMP). Thus, ATP priming of microglial cells underlies the ADP- and AMP-induced release of the inflammatory cytokine IL-1 $\beta$.

\section{DISCUSSION}

\section{Priming P2X $_{\mathbf{7}}$ with ATP}

$\mathrm{P} 2 \mathrm{X}_{7}$ purinoceptor defines a unique ATP-gated channel subtype with several distinct properties. It displays higher sensitivity to BzATP than to ATP and requires higher ATP concentrations for activation than other P2X receptors (Surprenant et al., 1996; Rassendren et al., 1997; Chessell et al., 1998). We have shown that stimulation of recombinant and microglial $\mathrm{P}_{2} \mathrm{X}_{7}$ receptors with ATP induces a dramatic increase in their sensitivity to the metabolites ADP and AMP, but not to UTP and adenosine. The fact that repeated application of ADP or AMP did not potentiate their own responses and that enhanced responses to both nucleotides can still be elicited after very low ATP concentrations indicates that ATP selectively primes $\mathrm{P} 2 \mathrm{X}_{7}$ receptors for activation by ADP or AMP. This dose-dependent priming effect can last several minutes beyond the complete recovery from ATP stimulation. This novel functional property of $\mathrm{P} 2 \mathrm{X}_{7}$ receptors is not common to all $\mathrm{P} 2 \mathrm{X}$ subtypes, because responses of $\mathrm{P} 2 \mathrm{X}_{2}$ receptors to ADP and AMP were not enhanced after ATP stimulation.

$\mathrm{P}_{2} \mathrm{X}_{7}$ subunits are characterized by the presence of a long $\mathrm{C}$-terminal domain involved in the formation of nonselective pores permeable to solutes as large as $900 \mathrm{Da}$ (Nuttle and Dubyak, 1994; Di Virgilio, 1995; Surprenant et al., 1996; Rassendren et al., 1997). We therefore thought of a direct relationship between the potentiated responses of $\mathrm{P} 2 \mathrm{X}_{7}$ receptors to ADP and AMP and the formation of large pores. However, our results demonstrated that both ADP and AMP failed to induce dilation of the pore, either alone or after priming with ATP. Moreover, the pore dilation cannot be achieved after a single brief application of ATP, and it requires repeated or sustained application over several minutes.

ATP priming induced an increase in ADP and AMP potency, clearly demonstrated by the absence of dose-dependent relationships for both nucleotides before ATP stimulation and the presence of sigmoidal dose-response relationships after ATP priming. This dramatic change of sensitivity for ADP and AMP 
A
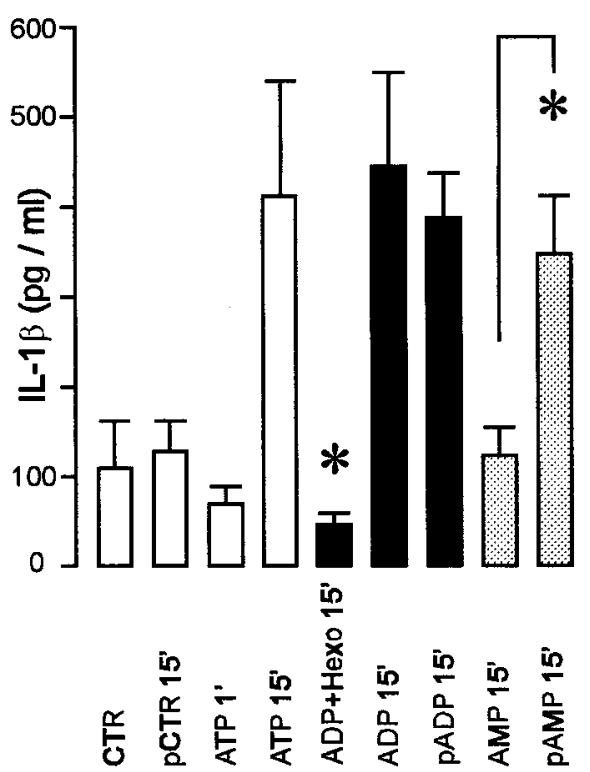

B

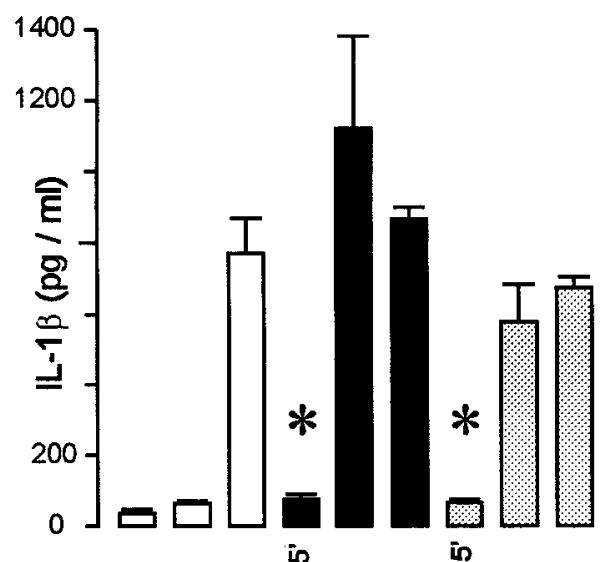

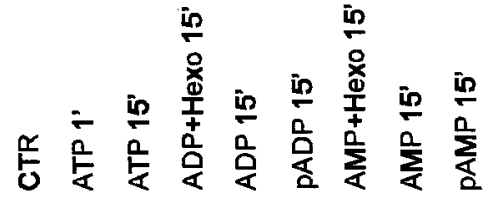

C

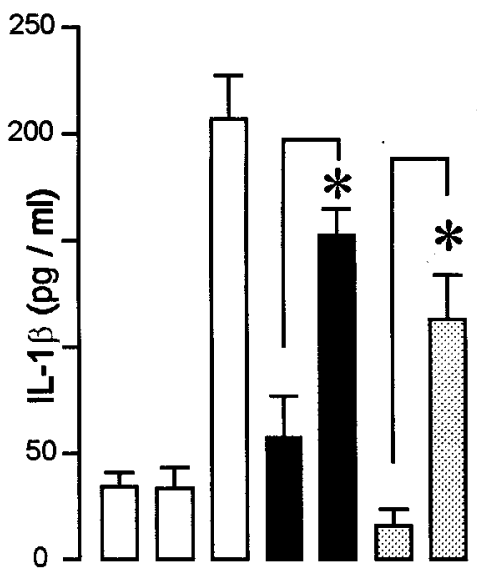

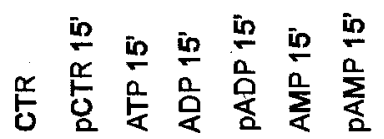

Figure 8. Nucleotide-induced IL- $\beta$ release from LPS-stimulated microglial cells. Released IL-1 $\beta$ (mean \pm SEM) from N9 mouse microglial cells $(A$, $2 \mathrm{~mm}$ ATP, $5 \mathrm{~mm}$ ADP, and $10 \mathrm{~mm}$ AMP), primary cultured mouse microglia (B, $2 \mathrm{~mm} \mathrm{ATP,} 10 \mathrm{~mm}$ ADP, and $10 \mathrm{~mm}$ AMP), and primary cultured human microglia $(C, 1 \mathrm{~mm}$ ATP, $10 \mathrm{~mm}$ ADP, and $10 \mathrm{~mm} \mathrm{AMP)}$ in response to stimulation with ATP and in response to ADP or AMP with and without previous priming with ATP is shown. $P A M P$ and $p A D P$ indicate that cells were primed with ATP for 2 min and then washed twice for 1 min before application of the nucleotide (in LPS-containing medium) for 15 min. $p C T R$ indicates that cells were primed with ATP for 2 min followed by two washes, and then the supernatant was taken at $15 \mathrm{~min}$. $A D P+$ Hexo or $A M P+H e x o$ indicates that cells were stimulated with LPS for 2 hr in the presence of hexokinase and glucose (as a substrate) before washout and addition of the indicated nucleotide for 15 min. * $p<0.05$. Open bars indicate CTR or ATP challenge, solid bars indicate ADP challenge, and gray bars indicate AMP challenge.

decreased with time. Therefore, ATP stimulation most likely triggers a reversible conformational change of $\mathrm{P} 2 \mathrm{X}_{7}$ receptor channels leading to modification of the agonist binding domain(s), of the gating properties of the channels, or of both. An increase in ATP potency without $\mathrm{P}_{2} \mathrm{X}_{7}$ pore enlargement was reported previously with repeated application of submaximal ATP concentrations (Hibell et al., 2000).

Activity-dependent phosphorylation or dephosphorylation of $\mathrm{P} 2 \mathrm{X}_{7}$ receptors is another candidate mechanism for mediating the ATP priming effect. Indeed, the intracellular domains of P2X subunits contain several potential protein kinase sites with functional impact (Koshimizu et al., 1999; Boué-Grabot et al., 2000; Kim et al., 2001). Alternatively, if this property of priming is not intrinsic to the $\mathrm{P} 2 \mathrm{X}_{7}$ receptors, it may be conferred on them by a conserved associated protein expressed both in Xenopus oocytes and in microglial cells.

\section{$\mathrm{P}_{2} \mathrm{X}_{7}$ priming and IL-1 $\beta$ release}

The release of IL-1 $\beta$ from immune cells is a two-step process. The first step requires transcription of the IL- $1 \beta$ gene and accumulation of pro-IL-1 $\beta$ in response to inflammatory stimuli, including bacterial endotoxins (LPS; Rothwell and Luheshi, 2000; Sanz and Di Virgilio, 2000). The second step involves maturation of IL- $1 \beta$ by ICE in preparation for its release (Perregaux and

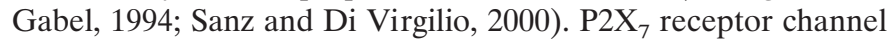
activation by ATP plays a critical role in this post-translational processing (Buell et al., 1998; Sanz and Di Virgilio, 2000). Our results demonstrated that the ADP-induced IL- $1 \beta$ release from mouse microglial cells and macrophages reported previously (Perregaux and Gabel, 1994; Ferrari et al., 1997b) is caused by priming of $\mathrm{P} 2 \mathrm{X}_{7}$ receptors located on these cells with endogenously released ATP in response to LPS stimulation (Ferrari et al., 1997b,c), as determined by the absence of ADP-induced IL- $1 \beta$ release when hexokinase was present during LPS stimulation (Fig. $8 A, B$ ). Hexokinase therefore prevents $\mathrm{P} 2 \mathrm{X}_{7}$ priming by ATP released from microglia. In addition, we demonstrated that priming of microglial cells by ATP (endogenously released or experimentally applied) underlies the release of IL- $1 \beta$ in response to AMP. The priming effect of ATP on ADP- and AMPinduced IL- $1 \beta$ release was more evident in human microglia, in which both nucleotides were effective only after experimental ATP priming. Moreover, in all preparations, the priming effect of ATP was stronger for ADP than for AMP, as demonstrated by the release of greater amounts of IL $-1 \beta$ in response to ADP.

These data are in good agreement with our electrophysiology results (Figs. $3 C$ and $6 C, D$ ), in which ADP and AMP were both ineffective in activating $\mathrm{P}_{2} \mathrm{X}_{7}$ receptors before ATP priming. Moreover, at any given concentration, the priming effect of ATP was more dramatic for ADP than for AMP (Fig. 4C,D). Thus, ATP priming of $\mathrm{P} 2 \mathrm{X}_{7}$ receptor channels underlies the ADP- and AMP-induced release of IL- $1 \beta$ from microglial cells.

\section{Physiological relevance}

The concentration of intracellular ATP falls in the millimolar range (e.g., 5-10 mm; Ferrari et al., 1997c). Therefore, it is not surprising that significant amounts of ATP can be present in the extracellular space because of cell damage after injury, infection, and ischemia. Extracellular ATP is hydrolyzed into ADP, then AMP, by surface ectonucleotidases, and AMP is converted into adenosine by $5^{\prime}$ nucleotidase activities (Zimmermann, 2000). The rate of this hydrolysis cascade depends locally on the expression levels and surface densities of the various ectonucleotidase isoforms displaying different relative affinities for ATP and ADP. For example, CD39 hydrolyzes both ADP and ATP at a similar 
ratio (ATP:ADP 1:0.8; Zimmermann, 2000). In contrast, CD39L1 preferentially hydrolyzes ATP (ATP:ADP 33:1; Zimmermann, 2000), thereby leading to accumulation of extracellular ADP. The priming of $\mathrm{P} 2 \mathrm{X}_{7}$ receptors most likely enhances the effects of extracellular nucleotides in vivo by sensitizing these ionotropic purinoceptors to ATP byproducts.

Unlike ATP, the functional roles of which are associated with cell death (Perregaux and Gabel, 1994; Di Virgilio, 1995; Ferrari et al., 1996, 1997c; Humphreys et al., 2000), the actions of ADP and AMP are not accompanied by cytotoxicity (Fig. 7). Therefore, these endogenous nucleotides may play more physiological roles in mediating the inflammatory reactions in the nervous system.

$\mathrm{P}_{2} \mathrm{X}_{7}$ receptor channels participate in multinucleated giant-cell formation (Di Virgilio et al., 1999), in lymphocyte proliferation (Baricordi et al., 1999), and in killing of intracellular mycobacteria (Kusner and Adams, 2000). In addition, ATP induces activation of the transcription factor nuclear factor of activated $\mathrm{T}$ cells (Ferrari et al., 1997d, 1999) and release of tumor necrosis factor- $\alpha$ (Hide et al., 2000) from macrophages and microglia through stimulation of $\mathrm{P} 2 \mathrm{X}_{7}$ receptors. Whether the selective sensitization of $\mathrm{P} 2 \mathrm{X}_{7}$ to ADP and AMP plays a role in the immune functions described above remains to be explored.

\section{REFERENCES}

Aloisi F, De Simone R, Columba-Cabezas S, Levi G (1999) Opposite effects of interferon- $\gamma$ and prostaglandin E2 on tumor necrosis factor and interleukin-10 production in microglia: a regulatory loop controlling microglia pro- and anti-inflammatory activities. J Neurosci Res 56:571-580.

Baricordi OR, Melchiorri L, Adinolfi E, Falzoni S, Chiozzi P, Buell G, Di Virgilio F (1999) Increased proliferation rate of lymphoid cells transfected with the P2X(7) ATP receptor. J Biol Chem 274:33206-33208.

Boué-Grabot E, Archambault V, Séguéla P (2000) A protein kinase C site highly conserved in $\mathrm{P} 2 \mathrm{X}$ subunits controls the desensitization kinetics of P2X(2) ATP-gated channels. J Biol Chem 275:10190-10195.

Buell G, Chessell IP, Michel AD, Collo G, Salazzo M, Herren S, Gretener D, Grahames C, Kaur R, Kosco-Vilbois MH, Humphrey PP (1998) Blockade of human P2X7 receptor function with a monoclonal antibody. Blood 92:3521-3528.

Buttini M, Sauter A, Boddeke HWGM (1994) Induction of interleukin-1 beta messenger RNA after focal cerebral ischaemia in the rat. Mol Brain Res 23:126-134.

Chessell JP, Simon J, Hibell AD, Michel AD, Barnard EA, Humphrey PP (1998) Cloning and functional characterization of the mouse P2X receptor. FEBS Lett 439:26-30.

Collo G, Neidhart S, Kawashima E, Kosco-Vilbois M, North RA, Buell G (1997) Tissue distribution of the P2X7 receptor. Neuropharmacology 36:1277-1283.

Di Virgilio F (1995) The P2Z purinoceptor: an intriguing role in immunity, inflammation and cell death. Immunol Today 16:524-528.

Di Virgilio F, Falzoni S, Chiozzi P, Sanz JM, Ferrari D, Buell GN (1999) ATP receptors and giant cell formation. J Leukoc Biol 66:723-726.

Ferrari D, Villalba M, Chiozzi P, Falzoni S, Ricciardi-Castagnoli P, Di Virgilio F (1996) Mouse microglial cells express a plasma membrane pore gated by extracellular ATP. J Immunol 156:1531-1539.

Ferrari D, Chiozzi P, Falzoni S, Dal Susino M, Melchiorri L, Baricordi OR, Di Virgilio F (1997a) Extracellular ATP triggers IL-1 $\beta$ release by activating the purinergic P2Z receptor of human macrophages. J Immunol 159:1451-1458.

Ferrari D, Chiozzi P, Falzoni S, Hanau S, Di Virgilio F (1997b) Purinergic modulation of interleukin $-1 \beta$ from microglial cells stimulated with bacterial endotoxin. J Exp Med 185:579-582.

Ferrari D, Chiozzi P, Falzoni S, Dal Susino M, Collo G, Buell G, Di Virgilio F (1997c) ATP-mediated cytotoxicity in microglial cells. Neuropharmacology 36:1295-1301.

Ferrari D, Wesselborg S, Bauer MK, Schulze-Osthoff K (1997d) Extracellular ATP activates transcription factor NF-kappaB through the P2Z purinoreceptor by selectively targeting NF-kappaB p65. J Cell Biol 139:1635-1643.

Ferrari D, Stroh C, Schulze-Osthoff K (1999) P2X7/P2Z purinoreceptor-mediated activation of transcription factor NFAT in microglial cells. J Biol Chem 274:13205-13210.

Garcia JH, Liu KF, Relton JK (1995) Interleukin-1 receptor antagonist decreases the number of necrotic neurons in rats with middle cerebral artery occlusion. Am J Pathol 147:1477-1486.
Giulian D, Baker TJ, Shin LN, Lachman LB (1986) Interleukin-1 of the central nervous system is produced by ameboid microglia. J Exp Med 164:594-604.

Hibell AD, Kidd EJ, Chessell IP, Humphrey PP, Michel AD (2000) Apparent species differences in the kinetic properties of P2X(7) receptors. Br J Pharmacol 130:167-173.

Hide I, Tanaka M, Inoue A, Nakajima K, Kohsaka S, Inoue K, Nakata Y (2000) Extracellular ATP triggers tumor necrosis factor-alpha release from rat microglia. J Neurochem 75:965-972.

Ho A, Blum M (1997) Regulation of astroglial-derived dopaminergic neurotrophic factors by interleukin-1 beta in the striatum of young and middle-aged mice. Exp Neurol 148:348-359.

Hopkins SJ, Rothwell NJ (1995) Cytokines and the nervous system. I. Expression and recognition. Trends Neurosci 18:83-88.

Humphreys BD, Rice J, Kertesy SB, Dubyak GR (2000) Stress-activated protein kinase/JNK activation and apoptotic induction by the macrophage P2X7 nucleotide receptor. J Biol Chem 275:26792-26798.

Kim M, Jiang LH, Wilson HL, North RA, Surprenant A (2001) Proteomic and functional evidence for a $\mathrm{P} 2 \mathrm{X}_{7}$ receptor signalling complex. EMBO J 20:6347-6358.

Koshimizu T, Koshimizu M, Stojilkovic SS (1999) Contributions of the $\mathrm{C}$-terminal domain to the control of P2X receptor desensitization. J Biol Chem 274:37651-37657.

Kusner DJ, Adams J (2000) ATP-induced killing of virulent Mycobacterium tuberculosis within human macrophages requires phospholipase D. J Immunol 164:379-388.

Li M, Ona VO, Guegan C, Chen M, Jackson-Lewis V, Andrews LJ, Olszewski AJ, Stieg PE, Lee JP, Przedborski S, Friedlander RM (2000) Functional role of caspase-1 and caspase- 3 in an ALS transgenic mouse model. Science 288:335-339.

Liu T, McDonnell PC, Young PR, White RF, Siren AL, Hallenbeck JM, Barone FC, Feuersein GZ (1993) Interleukin-1 beta mRNA expression in ischaemic rat cortex. Stroke 24:1746-1751.

Mahaut-Smith MP, Ennion SJ, Rolf MG, Evans RJ (2000) ADP is not an agonist at $\mathrm{P} 2 \mathrm{X}_{1}$ receptors: evidence for separate receptors stimulated by ATP and ADP on human platelets. $\mathrm{Br} \mathrm{J}$ Pharmacol 131:108-114.

Martin D, Near SL (1995) Protective effect of the interleukin-1 receptor antagonist (IL-1ra) on experimental allergic encephalomyelitis in rats. J Neuroimmunol 61:241-245.

Minami M, Kuraishi K, Yabuuchi K, Yamazaki K, Satoh M (1992) Induction of interleukin- $1 \beta$ mRNA in rat brain transient forebrain ischaemia. J Neurochem 58:390-392.

Nishimura M, Mizuta I, Mizuta E, Yamasaki S, Ohta M, Kuno S (2000) Influence of interleukin-1beta gene polymorphism on age-at-onset of sporadic Parkinson's disease. Neurosci Lett 284:73-76.

Nuttle LC, Dubyak GR (1994) Differential activation of cation channels and non-selective pores by macrophage $\mathrm{P} 2 \mathrm{z}$ purinergic receptors expressed in Xenopus oocytes. J Biol Chem 269:13988-13996.

Pasinelli P, Borchelt DR, Houseweart MK, Cleveland DW, Brown Jr RH (1999) Caspase-1 is activated in neuronal cells and tissue with amyotrophic lateral sclerosis-associated mutations in copper-zinc superoxide dismutase. Proc Natl Acad Sci USA 95:15763-15768.

Perregaux D, Gabel CA (1994) Interleukin-1 $\beta$ maturation and release in response to ATP and nigericin. J Biol Chem 269:15195-15203.

Rassendren F, Buell GN, Virginio C, Collo G, North RA, Surprenant A (1997) The permeabilizing ATP receptor, P2X7: cloning and expression of a human cDNA. J Biol Chem 272:5482-5486.

Relton JK, Rothwell NJ (1992) Interleukin-1 receptor antagonist inhibits ischaemic and excitotoxic neuronal damage in the rat. Brain Res Bull 29:243-246.

Righi M, Mori L, De Libero G, Sironi M, Biondi A, Mantovani A, Donini SD, Ricciardi-Castagnoli P (1989) Monokine production by microglial cell clones. Eur J Immunol 19:1443-1448.

Rothwell N, Allan S, Toulmond S (1997) The role of interleukin 1 in acute neurodegeneration and stroke: pathophysiological and therapeutic implications. J Clin Invest 100:2648-2652.

Rothwell NJ (1999) Cytokines: killers in the brain? J Physiol (Lond) 514:3-17.

Rothwell NJ, Luheshi GN (2000) Interleukin I in the brain: biology, pathology and therapeutic target. Trends Neurosci 23:618-625.

Sanz JM, Di Virgilio F (2000) Kinetics and mechanism of ATPdependent IL-1 $\beta$ release from microglial cells. J Immunol 164:4893-4898.

Schijver HM, Crusius JB, Uitdehaag BM, Garcia Gonzalez MA, Kostense PJ, Polman CH, Pena AS (1999) Association of interleukin-1beta and interleukin-1 receptor antagonist genes with disease severity in MS. Neurology 52:595-599.

Solle M, Labasi J, Perregaux DG, Stam E, Petrushova N, Koller BH, Griffiths RJ, Gabel CA (2001) Altered cytokine production in mice lacking P2X(7) receptors. J Biol Chem 276:125-132.

Surprenant A, Rassendren F, Kawashima E, North RA, Buell G (1996) The cytolytic P2Z receptor for extracellular ATP identified as a P2X receptor (P2X7). Science 272:735-738. 
Traverso-Cori A, Traverso S, Reyes H (1970) Different molecular forms of potato apyrase. Arch Biochem Biophys 137:133-142.

Vezzani A, Conti M, De Luigi A, Ravizza T, Moneta D, Marchesi F, De Simoni MG (1999) Interleukin-1 beta immunoreactivity and microglia are enhanced in the rat hippocampus by focal kainate application: functional evidence for enhancement of electrographic seizures. J Neurosci 19:5054-5065.

Vezzani A, Moneta D, Conti M, Richichi C, Ravizza T, De Luigi A, De Simoni MG, Sperk G, Andell-Jonsson S, Lundkvist J, Iverfeldt K, Bartfai T (2000) Powerful anticonvulsant action of IL-1 receptor antagonist on intracerebral injection and astrocytic overexpression in mice. Proc Natl Acad Sci USA 97:11534-11539.

Wang X, Franciosi S, Bae JH, Kim SU, McLarnon JG (1999) Expres- sion of $\mathrm{P} 2 \mathrm{y}$ and $\mathrm{P} 2 \mathrm{x}$ receptors in cultured human microglia. Proc West Pharmacol Soc 42:79-81.

Yamasaki Y, Suzuki T, Yamaya H, Matsuura N, Onodera H, Kogure K (1992) Possible involvement of interleukin-1 in ischemic brain edema formation. Neurosci Lett 142:45-47.

Yamasaki Y, Matsuura N, Shozuhara H, Onodera H, Itoyama Y, Kogure K (1995) Interleukin-1 as a pathogenetic mediator of ischemic brain damage in rats. Stroke 26:676-681.

Yong VW, Antel JP (1992) Culture of glial cells from human brain biopsies. In: Protocols for neural cell culture (Fedoroff S, Richardson A, eds), pp 81-96. New York: Plenum.

Zimmermann H (2000) Extracellular metabolism of ATP and other nucleotides. Naunyn Schmiedebergs Arch Pharmacol 362:299-309. 